\title{
Nancy Gonlin and April Nowell, Archaeology of the Night: Life after Dark in the Ancient World
}

\author{
Boulder: University Press of Colorado, 2018. e-book, 412 pp. ISBN \\ 9781607326786. £20.35.
}

\section{Ingrid $\bigcirc$ 'Donnell}

The chapters collected within this volume derive from two symposia assembled by the editors: the 2015 American Anthropological Association in Denver ("From Dusk to Dawn: Nightly Practices in the Ancient World") and the 2016 Society for American Archaeology meetings in Orlando ("Archaeology of the Night"). The book comprises eighteen chapters plus foreword and afterword and is divided into seven sections: (I) Introduction, (II) Nightscapes, (III) The Night Sky, (IV) Nocturnal Ritual and Ideology, (V) Illuminating the Night, (VI) Nighttime Practices and (VII) Concluding the Night.

Throughout, the standard privileging of archaeology of daytime activities rather than those of the night is highlighted and redress is sought by elucidating a wide spectrum of views of what an archaeology of the night might reveal. Already, it can be seen that my conventional sight-focused terminology belies current biases to privilege light and its conflation with understanding and knowledge. Consequently, I have tried to avoid visual terminology in this review but, as will be "seen", I have not succeeded. This book seeks to identify what perspectives and types of knowledge and understanding of past peoples can be gleaned from archaeology associated with the night.

The collection is to be commended in particular for its frequent recognition of modern Western biases and attempts to describe alternative ontological perspectives. Another interesting recurring theme is the observation that it is darkness, not light, that is most frequently considered primordial, and such cosmogonic connotations provide potential avenues for the identification of the lost beliefs and ontologies of previous societies (Chapter 10, p. 201). There are also some evocative descriptions of nighttime:

As night falls, illumination decreases. Simultaneously, temperatures drop and wind patterns change, bringing altered scents and humidity regimes. Some flowers open, others close; different mammals, birds and insects emerge. With the transformed 
sights, sounds, smells, and tactile sensations come new resources, but also a new set of real or imagined obstacles. (Kamp and Whittaker, p. 77)

This book is a treat, revealing why archaeologies of night are important for understanding the people of the past, including "technologies of illumination, the significance of lunar and stellar observations in creating cultural landscapes, the existence of complex nocturnal ontologies [as well as ...] specific valences, transgressions and meanings associated with darkness" (p. xviii).

The foreword by Jerry D. Moore sets the scene: "Despite spending roughly half of our lives in the night, our archaeological inquiries have been relentlessly diurnal" (p. xx). Polly Wiessner's work (Wiessner 2014) on the Ju/'hoansi, mobile foragers of the Kalahari, is referenced here and elsewhere in the volume, describing how daily conversations revolve around the three $\mathrm{Cs}$ - criticism, complaint and conflict - but at night, conversations mellow to storytelling of marriages, exchange of goods with neighbours and the journeys undertaken by trance healers to supernatural realms, perhaps accompanied by music and dance. Wiessner would have made an excellent additional contributor to this book. Moore compares these nighttime activities of the Ju/'hoansi to those of Christian monks of western Europe during Late Antiquity and the early Middle Ages, who might only sleep for five hours per night, rising at 2am to sing nocturns where "Night provided deep silence and quietude when one's thoughts could be more readily drawn to supernatural mysteries" (p. xix). He continues:

On one hand, these two examples of nocturnal behaviours are separated by time, place, cultural traditions, and ontology, and yet there are fascinating intersections between them: the special behaviours associated with nightly practices, the change between day and night in the sounds and subjects of human voices, and the rich cultural associations with darkness and the night. (p. xx)

An introduction to all the essays follows and I found myself wanting to race ahead to read about ancient technologies of illumination, such as fish-oil-burning lamps which illuminated the Viking so-called "Dark Ages" through the "long northern nights in a cosmos inhabited by dark figures such as werewolves, shape-changers and berserkers (Byock 1986)" (p. xx). It can be seen that this is going to be an eclectic collection of essays on a range of topics: the nocturnal soundscapes within Upper Palaeolithic caves; artificial illumination as a part of funeral rites in New Kingdom Egypt, where "light marked the liminal stage of 'the transition from day / life to night / death and rebirth'" (p. xxii); the nocturnal rituals of Mapuche female shamans, which complement the daytime rituals of their male counterparts; the ancient Mayan view that "night was the chaotic antithesis to bright diurnal day [...] a return to primordial time and chaos that made the night so potent" (p. xxii) (a theme referencing darkness and night as domains of creation that recurs throughout); the "cover of darkness [opening] the door to different types of ritual performances", discussed in several chapters ( $p$. xiii); the "intertwining of darkness and placemaking" (p.xxiv); the nighttime created by solar eclipses; and the various quotidian activities associated with nighttime such as water system maintenance at Mohenjodaro, iron smelting in South Africa, bread baking in Rome. "What the reader will discover is a 
surprisingly complex array of nocturnal worlds" (p. xxvii) with no universal associations of transgression or symbolic inversion.

Moore provides such a good, succinct overview of all the chapters that I have therefore tried to précis this above so that I can focus attention on my favourite chapters and those most relevant to skyscape archaeology, as well as on providing a few reservations about the book as a whole. Firstly, the book is a pleasure to read - an eclectic mix of subjects, as has already been pointed out, with some beautifully evocative writing. There are also many fascinating odd facts, such as in Glenn Reed Storey's Chapter 15, "All Rome is at my Bedside: Nightlife in the Roman Empire": did you know that it was difficult to sleep in Rome in the second century AD because there were traffic bans during the day, so all deliveries of goods requiring wheeled traffic had to be conducted at night (p. 308)? Or, that Pliny the Elder (who as we all know wrote an awful lot, mostly at night it turns out), died a hero? He commanded the Roman fleet that sailed out to assist the victims of Vesuvius in $79 A D$, but asphyxiated on the poisonous volcanic gases before arriving ( $p$. 322). Or that Romans believed in ghosts, werewolves, witches and shapeshifters, but that witches were more credible than werewolves, frequently associated with punishing men and contributing to the Roman fear of women wielding power (pp. 310-311)?

The theme of the female connection with the night is echoed in Tom Dillehay's Chapter 9, "Night Moon Rituals: The Effects of Darkness and Prolonged Ritual on Chilean Mapuche Participants", where he notes how female shamans, supported by ancestors and spirits, perform religious and ritual ceremonies primarily at night and thereby complement their male equivalents, who are mostly active during the day (p. 189). This chapter, however, mainly concentrates on the effects of nighttime Chilean Mapuche rituals on the human body, altered states of consciousness and mutualistic proprioception within crowds. Dillehay praises current recognition of "the more integrative concepts of symbolism, psychology and other effects of ritual participation", rather than the simple dichotomy identifying ritual practices as either symbolic or functional as was standard practice prior to the development of poststructuralism (p. 195). He considers the involvement of a wider, and more nuanced, range of factors influencing interpretation of ritual activities and their meaning and significance.

It is good to see Dillehay recommend consideration of the relations between the Mapuche rituals and the surrounding landscapes and skyscapes (pp. 191-192). Similarly, in Minette Church's earlier Chapter 5, "La Luz de Aceite es Triste: Nighttime, Community, and Memory in the Colorado-New Mexico Borderlands", the author not only acknowledges Lionel Sims' call for the term "landscape" to be broadened to include the "skyscape" (Sims 2009 , 389), but also gives voice to the fact that researchers not specifically investigating archaeoastronomy have "not always engaged with nocturnal cultural skyscapes as we should". She references Tim Ingold $(2007,20)$, who acknowledges that people who live in the open "do not live on the ground and under the sky but instead mingle with 'wind, light, and moisture of the sky' as they are bound with 'substances of the earth'" (p. 97). She also picks up on Sims' $(2009,391)$ comment, highly relevant today, that due to light pollution and the loss of dark skies, it is no longer always possible to visit ancient sites at night and "re-experience the monuments in the way their builders intended" (p. 115). 
Church's wholehearted recognition of the relevance and importance of skyscape archaeology and its contribution to comprehending past peoples and their beliefs is hopefully indicative of a turning point in archaeologists' and anthropologists' awareness of the benefits to be reaped by employing skyscape archaeological approaches.

Consideration of women's power also takes us to Susan M. Alt's Chapter 11, "The Emerald Site, Mississippian Women, and The Moon". Here we discover that "night in the Mississippian world belonged to women, because [...] the moon, the night sky, and reproduction were all aspects of feminine powers" (pp. 223-224). Alt adopts relational and symmetrical archaeological approaches to recognise the subjective and culturally constructed nature of reality and so to appreciate that Native American realities in the Mississippian culture were full of spirits, powers and things that may, or may not, have been visible, but that had agency and could be dangerous. Dreams and dream worlds may play a significant part in these realities; gender was non-binary, and reality was not always representational:

to say that women were related to the moon is not to say that the moon referenced, represented, or cited female powers, but that the moon was feminine power, and given the permeability and unbounded nature of people, powers, forces, and things, flesh-and-blood women shared that power - they were of the moon. (p. 226)

Alt argues that it should be acknowledged that both night and day, female and male, were honoured by past peoples and that North America's first city, Cahokia, and its Mississippian origins, owes a large part to the feminine powers of the night (pp. 223-224, 239).

It is perhaps apparent now that concern for an appropriate ontological perspective from which to view any archaeological studies of the night is a recurrent theme and a major strength of this book. This is evidenced right from Chapter 1, "Introduction to the Archaeology of the Night", where Gonlin and Nowell advocate for a parallax perspective "which essentially involves viewing one's subject from a different angle" and which they claim to have found extremely useful (p. 6) in combination with a variety of theoretical approaches such as traditional household archaeology, Pierre Bourdieu's practice theory and phenomenology. In Chapter 4, "The Night is Different: Sensescapes and Affordances in Ancient Arizona", Kathryn Kamp and John Whittaker employ Gibson's Affordance Theory to evaluate sensescapes and affordances of the night. They note that due to the positioning of rods and cones within the human retina, not only does night vision lack colour, objects on the periphery of human vision may become more noticeable; they also consider the importance of touch, smell, taste and heightened awareness of danger at night, suggesting this was possibly because "reliance on perceptions from senses other than vision may be [...] less trustworthy to visually-oriented humans" (pp. 80-81).

Continuing the theme of differing ontologies, Cynthia Van Gilder in Chapter 8 ,"In the Sea of Night: Ancient Polynesia and the Dark", explores the concept of Põ in Polynesia, which denotes not only night, but the world of spirits, the world of origins and the place below the horizon, beneath the sea - i.e., islands that appear on the horizon as one sails towards them. Van Gilder notes that "for a Hawaiian speaker in the centuries before European contact, the word Põ would have invoked all of these meanings simultaneously" 
(p. 157). It is interesting to consider that a concept similar to Põ, if not the actual word, resonates across time and space with Sims' proposition of the positioning of the underworld in respect to Neolithic processional routes to Avebury and Stonehenge (Sims 2009, 2020). Again, Van Gilder's prose at times is highly evocative:

it was really the night sky, bookended as it was with the rising and setting of the sun on the horizon, that brought a sense of location. At sea, at night, you knew where you were in the universe with a certainty that daytime in the middle of the ocean did not convey. (p. 161)

However, I would take issue with the statement that "historically there has not been much research into archaeoastronomy in Hawai'i" (p. 161) and would direct attention to authors such as Martha H. Noyes and Clive Ruggles for specifically Hawaiian archaeoastronomical research (Ruggles 2015, Noyes 2018), as well as to Artur Anyiszonyan for research into Pacific islanders' use of reciprocal star pairs as navigational aids (as presented at the European Association of Archaeologists Virtual Annual Meeting 2020, "The Archaeology of the Sky", in his talk "The Enigma of the Carolinian Sidereal Compass", which will hopefully be collated in a forthcoming proceedings publication).

Ontological considerations are also important in Alexie Vranich and Scott C. Smith's Chapter 6, "Nighttime Sky and Early Urbanism in the High Andes: Architecture and Ritual in the Southern Lake Titicaca Basin During the Formative and Tiwanaku Periods". They note that historically in archaeoastronomy, the solar cycle is given primacy; however, in this chapter, refreshingly, their focus is on the importance of the stars: "At 13,000 feet above sea level the rarefied air creates perfect celestial viewing conditions, and modern shamans know the best locations on the landscape to watch the stars 'play' with each other and the sacred mountains along the horizon" (p. 124). They state that from a viewing position, marked by a basalt stone in the middle of the north wall of the sunken court at Tiwanaku on the shore of Lake Titicaca, the Southern Cross (around which the Milky Way rotates) is observable directly above the tallest peak of the Quimsachata Mountain. Furthermore, between the pillars marking the singular entrance to the sunken court, an observer can witness the rising and setting of Alpha- and Beta-Centauri, also known as "the eyes of the llama" over the period when camelid herds were moved between highland and lowland pastures, paralleling Fabio Silva's suggestion that the view of Aldebaran rising over the mountains from a cluster of northwest Iberian Neolithic dolmens marked the transhumance of Old World ovicaprids from low to high ground (Silva 2015). Other alignments claimed include lunar standstills and equinox sunset and sunrise ( $p$. 130 ) and those involving dark cloud constellations (p. 125). Clear diagrams are presented to support these interesting claims, but to convince, more detail is required on the survey methodology and results, as well as regards levels of accuracy and uncertainty - a point exemplified in Silva's work.

Anthony Aveni in Chapter 7, "Night in Day: Contrasting Ancient and Contemporary Maya and Hindu Responses to Total Solar Eclipses", provides some fascinating thoughts on the anthropological consideration of eclipses, drawing attention again to the importance of ontological frameworks in archaeological investigations of the night. He aims to "high- 
light cross-cultural reactions to an extraordinary interruption of day-night periodicity" (p. 140). He comments that the nature of the darkening of the light during solar eclipses is unique and does not fit within the epistemological and temporal framework of the modern West. Consequently, he calls for new anthropological investigation into eclipse watching to provide answers for questions such as "What do people's portrayals of eclipses tell us about their religion, their beliefs in the afterlife, their social cohesion?" (p. 142).

Aveni's chapter, like all the chapters in this book, is fascinating. However, appropriately perhaps for a chapter on eclipses, it rings a note of discord that echoes through the book as a whole: the book is titled "Archaeology of the Night", but solar eclipses are not nighttime events. Similarly, Nowell's Chapter 2, "Upper Paleolithic Soundscapes and the Emotional Resonance of Nighttime", tries hard to fit in too, but it too is about darkness and not specifically night. It is a wonderful and thought-provoking chapter, which explores the question of whether people are more emotionally sensitive at night and, as with Aveni's chapter, I am glad it was included. So, this leads to the question of whether the title of the book could have been more apt. "The Archaeology of Darkness" would have been much more fitting, but of course, another book of this title by Marion Dowd and Robert Hensey, exploring how humans might have interacted with darkness in prehistoric caves and monuments, had been published two years previously (Dowd and Hensey 2016). Gonlin and Nowell's volume has a broader and more ambitious remit in also encompassing human responses to night, with frequent consideration of ontological as well as cosmological perspectives.

Much of the contextual information provided is anthropological in nature, leading one to wonder once more about the title: might "Anthropology of the Night" have been better (particularly as both editors refer to themselves as "we, as anthropologists" in the first chapter [p. 13])? But yet again, this title has been taken already (for example, Galinier et al. 2010, Burkhard and Ben-Ari 2005). Nevertheless, the title's focus on archaeology enables consideration of key nighttime material features such as hearths (for example, Chapters 3, 9, 17), techniques of illumination (in Section V, 'llluminating the Night', including considerations of the artificial lighting methods adopted by ancient Egyptians in Chapter 12 and by Vikings in Chapter 13) and the examination of material remains from predominantly nighttime activities (in Section VI "Nighttime Practices", including sanitation works in Chapter 14; writing, transport logistics and sex [or not] in Chapter 15; water management, with reference to stellar timekeeping, in Chapter 16; smelting in Chapter 17; and socially prescribed activities in Chapter 18). Of these, it is the cosmological and ontological interpretations provided in Chapter 12, "A Great Secret of the West: Transformative Aspects of Artificial Light in New Kingdom Egypt", by Meghan Strong, which appeals most to the biases of this reviewer. It provides a fascinating review of artificial lighting as an intermediary between the worlds of light and dark in ancient Egypt, and concludes that night was an aspect of the world that needed to be embraced and was particularly relevant to funerals and transitions between life, death and rebirth.

Another feature of Gonlin and Nowell's book is its length: 412 pages, most of which are not dedicated to "Archaeology of the Night" but rather to setting the scene and providing the contextual information so that topics relevant to archaeology of the night 
can be discussed from an informed position. This is absolutely necessary, but much of the information provided is also relevant to "archaeology of the day", which then begs the questions of whether a separate archaeology of the night is really necessary or, if archaeology in general just needs to be more inclusive of its dark twin.

Lastly, in their introduction, Gonlin and Nowell claim that they aim to showcase studies from around the globe and from different time periods. However, without doubt, there is a focus on New World case histories throughout (twelve of the eighteen chapters have a New World focus, leaving six to cover Asia, Africa, Polynesia and Europe). Moore's foreword inclusion of Christian monks of medieval western Europe is the exception, and, sadly, there was no further reference to the eagerly anticipated Viking "werewolves, shape-changers, and berserkers" (p. xxii) in McGuire's still interesting Chapter 13, "Burning the Midnight Oil: Archaeological Experiments with Early Medieval Viking Lamps".

These minor reservations aside, Archaeology of the Night is a fascinating "pick and mix" of topics highlighting the wide range of viewpoints that could be taken to ensure that nighttime activities, which take up half the lives of the people investigated by archaeologists, are given their full due, and thereby helping to ensure that the aphorism "Our entire history is only the history of waking men" (p. xvii) remains wrong on multiple counts for forever more. As previously mentioned, the book is as much an anthropology, as an archaeology, of the night, and as such, together with its appreciation of different ontological perspectives, it provides a valuable reference for skyscape archaeologists and others with the shared aim of striving to interpret relationships between people and the sky.

\section{References}

Burkhard, S. and E. Ben-Ari, 2005. “Introduction: 'When Darkness Comes...': Steps Toward an Anthropology of the Night". Paidemua: Mitteilungen zur Kulturkunde 51: 153-163.

Byock, J., 1986. "The Dark Figure as Survivor in an Icelandic Saga". In The Dark Figure in Medieval German and Germanic Literature, edited by E. R. Haymes and S. C. Van E'eleden, 151-163. Göppinger Arbeiten zur Germanistik 448. Göppingen: Kümmerle Verlag.

Dowd, M. and R. Hensey, 2016. The Archaeology of Darkness. Oxford: Oxbow Books. https://doi.org/10.2307/j. ctvh1dng1

Galinier, J., A. M. Becquelin, G. Bordin, L. Fontaine, F. Fourmaux, J. R. Ponce, P. Salzarulo, P. Simonnot, M. Therrien and I. Zilli, 2010. "Anthropology of the Night: Cross-Disciplinary Investigations". Current Anthropology 51 (6): 819-847. https://doi.org/10.1086/653691

Ingold, T., 2007. "Earth, Sky, Wind, and Weather". Journal of the Royal Anthropological Institute 13 (Suppl. 1): S19-S38. https://doi.org/10.1111/j.1467-9655.2007.00401.x

Noyes, M., 2018. "Solar Nadirs in Pre-Contact Hawaiian Cultural Astronomy". Journal of Skyscape Archaeology 4 (2): 201-229. https://doi.org/10.1558/jsa.34369

Ruggles, C. L. N., 2015. "Ancient Hawaiian Astronomy". In Handbook of Archaeoastronomy and Ethnoastronomy, edited by C. L. N. Ruggles, 2247-2260. New York: Springer. https://doi.org/10.1007/978-1-4614$6141-8 \quad 244$

Silva, F., 2015. "The View from Within: a 'Time-Space-Action' Approach to Megalithism in Central Portugal". In Skyscapes: The Role and Importance of the Sky in Archaeology, edited by F. Silva and N. Campion, 120139. Oxford: Oxbow Books. https://doi.org/10.2307/j.ctvh1dksg.14

Sims, L., 2009. “Entering, and Returning from, the Underworld: Reconstituting Silbury Hill by Combining a 
Quantified Landscape Phenomenology with Archaeoastronomy". Journal of the Royal Anthropological Institute 15 (2): 386-408. https://doi.org/10.1111/j.1467-9655.2009.01559.x

Sims, L., 2020. "Through the Dark Vale: Interpreting the Stonehenge Palisade through Interdisciplinary Convergence". Journal of Skyscape Archaeology 6 (1): 5-29. https://doi.org/10.1558/jsa.38690

Wiessner, P., 2014. "Embers of Society: Firelight Talk among the Ju/'hoansi Bushmen". Proceedings of the National Academies of Science 11 (39): 14027-14035. https://doi.org/10.1073/pnas.1404212111 